\title{
Short-Term Training of Family Medicine Teams on Cardiovascular Risk Assessment and Management - Effects on Practice and Outcomes
}

\author{
Savka Štrbac, ${ }^{1}$ Nataša Pilipović Broćeta, ${ }^{2,5}$ Nevena Todorović, ${ }^{2,} 5$ Vesna \\ Vujić Aleksić, ${ }^{3,5}$ Siniša Stević, ${ }^{3}$ Amela Lolić, ${ }^{4}$ Alen Šeranić, ${ }^{4}$ Duško Vulić, ${ }^{5}$ \\ Dubravko Bokonjić, ${ }^{5}$ Ranko Škrbićs
}

\begin{abstract}
Background/Aim: The prevention of cardiovascular risk factors and cardiovascular disease management contributes to the cardiovascular mortality reduction. The effects of these activities have been measured by quality indicators. The aim of this study was to determine the effects of family medicine team training workshop and implementation of clinical guidelines on the cardiovascular risk factors and diseases management in primary health care in the Republic of Srpska/Bosnia and Herzegovina.

Methods: The "CardioVascular Risk Assessment and Management" study included a sample of 373 teams from 41 primary health care centres trained to provide adequate services and to compare the quality of cardiovascular risk management before and after the training workshop and implementation of clinical guidelines. The comparison was based on nine project defined performance indicators related to hypertension, type 2 diabetes mellitus, hyperlipidaemia, tobacco smoking and obesity.

Results: Significant improvements were observed in six indicators after the training workshop and implementation of guidelines. Target values for blood pressure and $\mathrm{HbA} 1 \mathrm{c}$ were achieved in over $80 \%$ of patients $(82.12 \pm 15.81$ vs $84.49 \pm 12.71$ and $84.49 \pm 12.71$ vs $85.49 \pm 24.55$; before and after the training workshop, respectively), while the target values for LDL cholesterol were achieved in $54.98 \% \pm 20.33$ before and $57.64 \% \pm 16.66$ after the training workshop. The number of teams that had less than $20 \%$ of recorded data significantly decreased after the training workshop and guidelines implementation, and adequate recording of all indicators was improved.

Conclusion: The training workshop of family medicine teams and implementation of clinical guidelines resulted in significant quality improvement of cardiovascular diseases management in primary health care.
\end{abstract}

Key words: Family medicine team; Clinical guidelines; Cardiovascular risk factors; Quality indicators; Prevention.
(1) Public Health Institute of the Republic of Srpska, Banja Luka, the Republic of Srpska, Bosnia and Herzegovina.

(2) Family Medicine Teaching Centre, Primary Health Care Centre Banja Luka, Banja Luka, the Republic of Srpska, Bosnia and Herzegovina.

(3) Certification department, Agency for Certification, Accreditation and Health Care Quality Improvement of the Republic of Srpska, Banja Luka, the Republic of Srpska, Bosnia and Herzegovina.

(4) Sector for Public Health, International Relations and European Integration, Ministry of Health and Social Welfare, the Republic of Srpska, Banja Luka, The Republic of Srpska, Bosnia and Herzegovina.

(5) Centre for Biomedical Research, Faculty of Medicine, University of Banja Luka, Banja Luka the Republic of Srpska, Bosnia and Herzegovina.

Correspondence:

SAVKA ŠTRBAC

E: savka.strbac@phi.rs.ba

ARTICLE INFO

Received: 2 September 2021 Revision received: 29 September 2021 Accepted: 29 September 2021

\section{Introduction}

Chronic non-communicable diseases account for $74 \%$ of deaths worldwide, of which $31 \%$ has been caused by cardiovascular diseases (CVD).,
In the Republic of Srpska (RS), Bosnia and Herzegovina (B\&H), the CVDs cause $47.3 \%$ of total mortality. ${ }^{3}$ The RS is one of the two constitutive

Copyright $\odot 2021$ Šrrbac et al. This is an open access article distributed under the Creative Commons Attribution License (CC BY), which permits unrestricted use, distribution, and reproduction in any medium, provided the original work is properly cited. This article should be cited as follows: Štrbac S, Pilipović Broćeta N, Todorović N, Vujić Aleksić V, Stević S, Lolić A, et al. Short-term training of family medicine teams on cardiovascular risk assessment and management - effects on practice and outcomes. Scr Med 2021 Sep;52(3):165-73. 
entities in B\&H with the total population of 1170 342 people. ${ }^{4}$ Based on Low on Health Protection of the RS, the primary health care (PHC) is the foundation of health care system which is organised on municipality level and regulated, controlled and conducted by Ministry of Health and Social Welfare of the RS and financed by Health Insurance Fund of the RS. ${ }^{5}$ Measures of health promotion, disease prevention, early detection and timely treatment at PHC level should be able to solve most of health problems and address most of population health requirements. The main pillar of PHC in the RS is family medicine team (FMT). FMT is the basic organisational form of delivering PHC, and basic organisational structure that holds most activities at the PHC level. FMTs can be organised as freestanding FMT (independent legal entity; public or private), group practice or FMT within a PHC Centre (PHCC) as its internal organisational unit. FMT consists of a general practitioner with specialisation in family medicine, or specialist in other branches of medicine who have completed program of additional education in family medicine and two nurses who have completed program of additional nursing education in family medicine. FMTs are primary "gateway" for citizens/patients or entry points into the health system. FMT works in family medicine ambulance which is a PHC setting integrated into and operate within PHCC. PHCC (Dom Zdravlja) - is a public health institution that organises its work according to FM model on municipality level. So, the total number of PHCC in is 54 corresponding to the number of municipalities in the RS. First contact with health system or an entry point for citizens is operated through FMT. The total number of FMT in RS is 698, and one FMT can register from 500 to 830 families, representing between 1,500 and 2,500 inhabitants. The FMT's are locally organised and its number and composition, as well as the corresponding municipality population, remain rather stable over the long period of time.

The association of family practitioners has played a great role in the education and implementation of clinical guidelines as two most important activities for achieving better health outcomes. ${ }^{6,7}$ Cardiovascular risk factors are classified as modifiable and non-modifiable risk factors. ${ }^{8}$ It is well known that prevention of modifiable risk factors and management of patients with CVD contribute to the reduction of CVD mortality. The effects of these activities have been measured by quality indicators. ${ }^{7,8}$ A systematic review of 38 studies showed the role of educational intervention in improvement of CVD prevention, guideline implementation and clinical outcome. ${ }^{6}$ Audit based education in the United Kingdom and multimodal intervention in the United States of America and Italy has resulted in better achieving of target values for blood pressure and cholesterol. The analysis recognised a need for complex approach in preventing multiple risk factors in patients since guidelines dissemination alone had not improved adherence nor clinical. ${ }^{6}$

The project "Reducing Health Risk Factors in Bosnia and Herzegovina - Developing and Advancing Modern and Sustainable Public Health Strategies, Capacities and Services to Improve Population Health in Bosnia and Herzegovina" was developed jointly by the Swiss Agency for Development and Cooperation (SDC), the World Health Organisation (WHO) Regional Office for Europe, the WHO Country Office in B\&H and the health authorities in B\&H (2013-2019)..$^{9}$ The main goal of this project was a comprehensive intervention for improving CVD prevention and standardisation of "CardioVascular Risk Assessment and Management" (CVRAM) in FM. The project activities included the development of clinical guidelines, short term training workshop and determination of indicators for evaluation of educational effects (baseline assessment and post CVRAM training evaluation). There have been several clinical guidelines developed within the project: Guideline for Prevention and Treatment of Hypertension, Guideline for Prevention and Treatment of Diabetes Mellitus and Cardiovascular Diseases, Guideline for Prevention and Treatment of Hyperlipidaemia, Guideline for Prevention of Child Obesity, Guideline for Prevention of Adult Obesity, Guideline for Promotion of Physical Activity, and Guideline for Smoking Cessation. After the development and full adoption, the guidelines were used as educational tools for FMT training workshop process.

The aim of this study was to evaluate the effects of short training workshop of FMTs and implementation of clinical guidelines on the management of patients with modifiable cardiovascular risk factors, CVDs and type 2 diabetes mellitus (T2DM) in primary health care centres in the RS/ $\mathrm{B} \& \mathrm{H}$. 


\section{Methods}

\section{Study participants}

The study included 373 FMTs from 41 primary healthcare centres (367 FMTs from 35 public PHCC and 6 FMTs from 6 private healthcare centres). The inclusion criteria for FMTs participation in the project were as follows: completed CVRAM training, implementation of clinical guidelines, population registered to FMT before 1 July 2015, and all data available in patient electronic medical records.

There were no ethical issues in this research, so there was no need for formal approval by the ethics committee. The values of the quality indicators were extracted from the electronic database of the primary health care. The data on FMTs and observed registered population were anonymous.

\section{Intervention}

The CVRAM training workshop of FMTs was implemented by Departments of Family Medicine of two faculties of medicine in RS; Banja Luka Faculty of Medicine, University of Banja Luka, and Foča Faculty of Medicine, University of Eastern Sarajevo. The trainings consisted of two days educational program on the implementation of clinical guidelines for cardiovascular risk assessment, planning of prevention activities and education on appropriate recording of data in electronic medical records. The CVRAM training workshops were held in the three teaching cities, Banja Luka, Doboj and Foča, representing adequate territorial coverage of the country, in a period of one year; from 30 June 2016 to 1 July 2017. The training workshop was conducted by a defined number of trained family medicine teaching experts to ensure standardisation.

\section{Data collection}

Medical documentation of all patients in family medicine was kept as a patient electronic medical records in a web based information system for family medicine and stored centrally in the electronic database. For the purpose of this study specific data of female and male patients were extracted: the average of the last two measured values of blood pressure (BP) in patients with hypertension, last measured glycated haemoglobin (HbA1c) value in patients with T2DM, last measured low-density lipoprotein (LDL) cholesterol value in patients with hyperlipidaemia (LDL cholesterol $\geq 4.1 \mathrm{mmol} / \mathrm{L}$ ), body weight in patients with body mass index (BMI) $\geq 30 \mathrm{~kg} / \mathrm{m}^{2}$ and history of tobacco smoking. The data on diagnosis for hypertension, T2DM, hyperlipidaemia and obesity were based on physician diagnosis according to ICD10 coding.

The reliability of the data was ensured by comparison with the data from the registers for chronic diseases at the level of the FMT: (1) Registry of patients with hypertension, (2) Registry of patients with T2DM (3) Registry of patients with hyperlipidaemia, (4) Registry of obese patients (BMI $\geq 30 \mathrm{~kg} / \mathrm{m}^{2}$ ), (5) Registry of patients with hyperlipidaemia and T2DM who were prescribed statin therapy, (6) Registry of patients $\geq 18$ years of age with a recorded tobacco smoking status.

Existing data information system was designed for primary healthcare system of the Republic of Srpska and it can easily provide the extraction of all needed data for further analysis including the data which can serve as specific indicators for this study.

\section{Measures}

Before FMT training workshop nine quality indicators were developed by the project. The evaluation was based on these previously identified indicators that were measured as process indicators and outcome indicators (Table 1).

\section{Observation period}

The baseline assessment was performed one year before the CVRAM training workshop and guidelines implementation (1 July 2015 - 30 June 2016) and post training and guidelines implementation evaluation was performed one year after the CVRAM training workshop was finished (1 July 2017- 30 June 2018).

\section{Statistical analysis}

The statistical analysis was done by means of statistical software package, SPSS Statistics v. 18, USA. Most of the variables were presented as frequency of certain categories, while statistical significance of differences was tested with the Chisquared test or two sample t-test of proportion. The most important results were presented by mean percent values \pm standard deviations (SD). The relationship between the two variables was established by using a Pearson correlation analysis. Probability $(p<0.05)$ was chosen as a limit for statistical significance between two groups. 
Table 1: The list of CVRAM indicators

\begin{tabular}{|c|c|c|c|}
\hline No & Indicator & Type & Calculation formula \\
\hline 1. & $\begin{array}{l}\text { Percentage of hypertensive patients with } \\
\text { BP measurements recorded within the last } \\
12 \text { months }\end{array}$ & process & $\begin{array}{l}\text { Nominator is the number of patients with hypertension who had a } \\
\text { record of BP measurement in last } 12 \text { months. } \\
\text { Denominator is the number of patients with hypertension. }\end{array}$ \\
\hline 2. & $\begin{array}{l}\text { Percentage of patients with hypertension } \\
\text { with recorded value of } B P \geq 140 / 90 \mathrm{mmHg} \\
\text { in last } 12 \text { months }\end{array}$ & outcome & $\begin{array}{l}\text { Nominator is the number of patients with hypertension who had a } \\
\text { record of BP measurement in last } 12 \text { months and the value of that BP } \\
\text { was } \geq 160 / 100 \text { mmHg. } \\
\text { Denominator is the number of patients with hypertension who had a } \\
\text { record of BP measurement in last } 12 \text { months. }\end{array}$ \\
\hline 3. & $\begin{array}{l}\text { Percentage of } \mathrm{HbA1c} \text { measurements among } \\
\text { T2DM patients in last } 12 \text { months }\end{array}$ & process & $\begin{array}{l}\text { Nominator is the number of patients with T2DM who had a record of } \\
\text { HbA1c measurement in last } 12 \text { months. } \\
\text { Denominator is the number of patients with T2DM. }\end{array}$ \\
\hline 4. & $\begin{array}{l}\text { Percentage of patients with T2DM with } \\
\text { measured } \mathrm{HbA} 1 \mathrm{c} \text { level } \geq 7 \% \text { in last } \\
12 \text { months }\end{array}$ & outcome & $\begin{array}{l}\text { Nominator is the number of patients with T2DM who had a record of } \\
\text { HbA1c measurement in last } 12 \text { months and value of } \mathrm{HbA} 1 \mathrm{c} \text { was } \geq 9.0 \% \text {. } \\
\text { Denominator is the number of patients with T2DM who had a record of } \\
\text { HbA1c measurement in last } 12 \text { months. }\end{array}$ \\
\hline 5. & $\begin{array}{l}\text { Percentage of patients with hyperlipidaemia } \\
\text { with recorded LDL cholesterol measure- } \\
\text { ment in the last } 12 \text { months }\end{array}$ & process & $\begin{array}{l}\text { Nominator is the number of patients with hyperlipidaemia who had a } \\
\text { record of LDL cholesterol measurement in last } 12 \text { months. } \\
\text { Denominator is the number of patients with hyperlipidaemia. }\end{array}$ \\
\hline 6. & $\begin{array}{l}\text { Percentage of patients with hyperlipidaemia } \\
\text { with recorded } \mathrm{LDL} \text { cholesterol } \geq 3 \mathrm{mmol} / \mathrm{L} \\
\text { in the last } 12 \text { months. }\end{array}$ & outcome & $\begin{array}{l}\text { Nominator is the number of patients with hyperlipidaemia who had a } \\
\text { record of } L D L \text { cholesterol measurement in last } 12 \text { months and value of } \\
\mathrm{LDL} \text { cholesterol } \geq 4.1 \mathrm{mmol} / \mathrm{L} \text {. Denominator is the number of patients } \\
\text { with hyperlipidaemia who have a record of } \mathrm{LDL} \text { cholesterol measure- } \\
\text { ment in last } 12 \text { months. }\end{array}$ \\
\hline 7. & $\begin{array}{l}\text { Percentage of patients with T2DM with } \\
\text { recorded } L D L \text { cholesterol } \geq 3 \mathrm{mmol} / \mathrm{L} \text { who } \\
\text { were prescribed statin therapy in the last } \\
12 \text { months }\end{array}$ & $\begin{array}{l}\text { process } \\
\text { outcome }\end{array}$ & $\begin{array}{l}\text { Nominator is the number of patients with T2DM who had measured LDL } \\
\text { cholesterol greater than } 4.1 \mathrm{mmol} / \mathrm{L} \text { in the last } 12 \text { months and who were } \\
\text { prescribed statins. } \\
\text { Denominator is the number of patients with T2DM whom had measured } \\
\mathrm{LDL} \text { cholesterol } \geq 4.1 \mathrm{mmol} / \mathrm{L} \text { in the last } 12 \text { months }\end{array}$ \\
\hline 8. & $\begin{array}{l}\text { Percentage of patients older than } 18 \text { with } \\
\text { recorded tobacco smoking status }\end{array}$ & process & $\begin{array}{l}\text { Nominator is the number of patients older than } 18 \text { with recorded tobacco } \\
\text { smoking status. } \\
\text { Denominator is a number of patients older than } 18 .\end{array}$ \\
\hline 9. & $\begin{array}{l}\text { Percentage of body weight measurements } \\
\text { recorded in the last } 12 \text { months with obese } \\
\text { patients }\left(\mathrm{BMI} \geq 30 \mathrm{~kg} / \mathrm{m}^{2}\right)\end{array}$ & process & $\begin{array}{l}\text { Nominator is the number of patients with obesity who had a record of } \\
\text { body weight in the last } 12 \text { months. } \\
\text { Denominator is the number of obese patients }\left(\mathrm{BMl} \geq 30 \mathrm{~kg} / \mathrm{m}^{2}\right)\end{array}$ \\
\hline
\end{tabular}

*All indicators were calculated in relation to the registered population in FMT, older than 18 years. CVRAM: CardioVascular Risk Assessment and Management, BP: blood pressure; LDL: low-density lipoprotein, T2DM: type 2 diabetes mellitus, BMI: body mass index.

\section{Results}

Out of a total of 698 FMTs, 483 of them completed the CVRAM training workshop. However, only 373 FMTs (53.44 \%) were included in the evaluation due to the accuracy of data provided from their data electronic system.

\section{Baseline assessment}

The baseline assessment showed that many of process indicators were not accomplished in a great percentage of measures. Monitoring of hypertensive patients and recording of BP values were neither properly recorded nor recorded at all in the patient's electronic medical records.
Monitoring of T2DM patients was poor in more than a half of the FMTs, with inadequate recording of HbA1c and LDL values. There was a small percentage of recorded body weight values of obese patients in the majority of FMTs. The same was confirmed for recording the patient's tobacco smoking status. The values of these indicators are shown in Table 2.

\section{Post training evaluation}

The significant improvement was confirmed for six out of nine analysed indicators. A slight comparative difference in terms of deterioration was 
Table 2: Trend of indicators before and after CVRAM training workshop

\begin{tabular}{|c|c|c|c|c|c|}
\hline No & Indicator & Baseline N (\%) & Post training N (\%) & Improvement & $p$ value \\
\hline 1. & $\begin{array}{l}\text { Percentage of hypertensive patients with } \\
\text { BP measurements recorded within the last } \\
12 \text { months }\end{array}$ & $124931(57.40)$ & $125655(57.06)$ & NO & 0.001 \\
\hline 2. & $\begin{array}{l}\text { Percentage of hypertensive patients with } \\
\text { recorded value of } B P \geq 160 / 100 \mathrm{mmHg} \text { in } \\
\text { last } 12 \text { months }\end{array}$ & 74112 (17.88) & 77687 (15.51) & YES & 0.001 \\
\hline 3. & $\begin{array}{l}\text { Percentage of HbA1c measurements among } \\
\text { T2DM patients in last } 12 \text { months }\end{array}$ & $26966(36.43)$ & 30316 (41.39) & YES & 0.001 \\
\hline 4. & $\begin{array}{l}\text { Percentage of patients with T2DM with } \\
\text { measured } \mathrm{HbA1c} \text { level } \geq 9.0 \% \text { in last } \\
12 \text { months }\end{array}$ & 10709 (17.36) & 13408 (14.51) & YES & 0.001 \\
\hline 5. & $\begin{array}{l}\text { Percentage of patients with hyperlipidaemia } \\
\text { with recorded LDL cholesterol measurement } \\
\text { in the last } 12 \text { months }\end{array}$ & 36905 (34.09) & $55496(36.50)$ & YES & 0.001 \\
\hline 6. & $\begin{array}{l}\text { Percentage of patients with hyperlipidaemia } \\
\text { with recorded } \mathrm{LDL} \text { cholesterol } \geq 4.1 \mathrm{mmol} / \mathrm{L} \\
\text { in the last } 12 \text { months }\end{array}$ & 16448 (45.02) & 24687 (42.36) & YES & 0.001 \\
\hline 7. & $\begin{array}{l}\text { Percentage of patients with T2DM with re- } \\
\text { corded LDL cholesterol } \geq 4.1 \mathrm{mmol} / \mathrm{L} \text { whom } \\
\text { were prescribed statin therapy in the last } \\
12 \text { months }\end{array}$ & $1433(64.48)$ & $1797(62.76)$ & NO & 0.320 \\
\hline 8. & $\begin{array}{l}\text { Percentage of patients older than } 18 \text { with } \\
\text { recorded smoker's status }\end{array}$ & 567732 (17.92) & $570874(26.70)$ & YES & 0.001 \\
\hline 9. & $\begin{array}{l}\text { Percentage of body weight measurements } \\
\text { recorded in the last } 12 \text { months with obese } \\
\text { patients }\left(\mathrm{BMI} \geq 30 \mathrm{~kg} / \mathrm{m}^{2}\right)\end{array}$ & 26997 (36.79) & 34432 (29.19) & NO & 0.001 \\
\hline
\end{tabular}

CVRAM: CardioVascular Risk Assessment and Management, BP: blood pressure; LDL: low-density lipoprotein, T2DM: type 2 diabetes mellitus, BMI: body mass index.

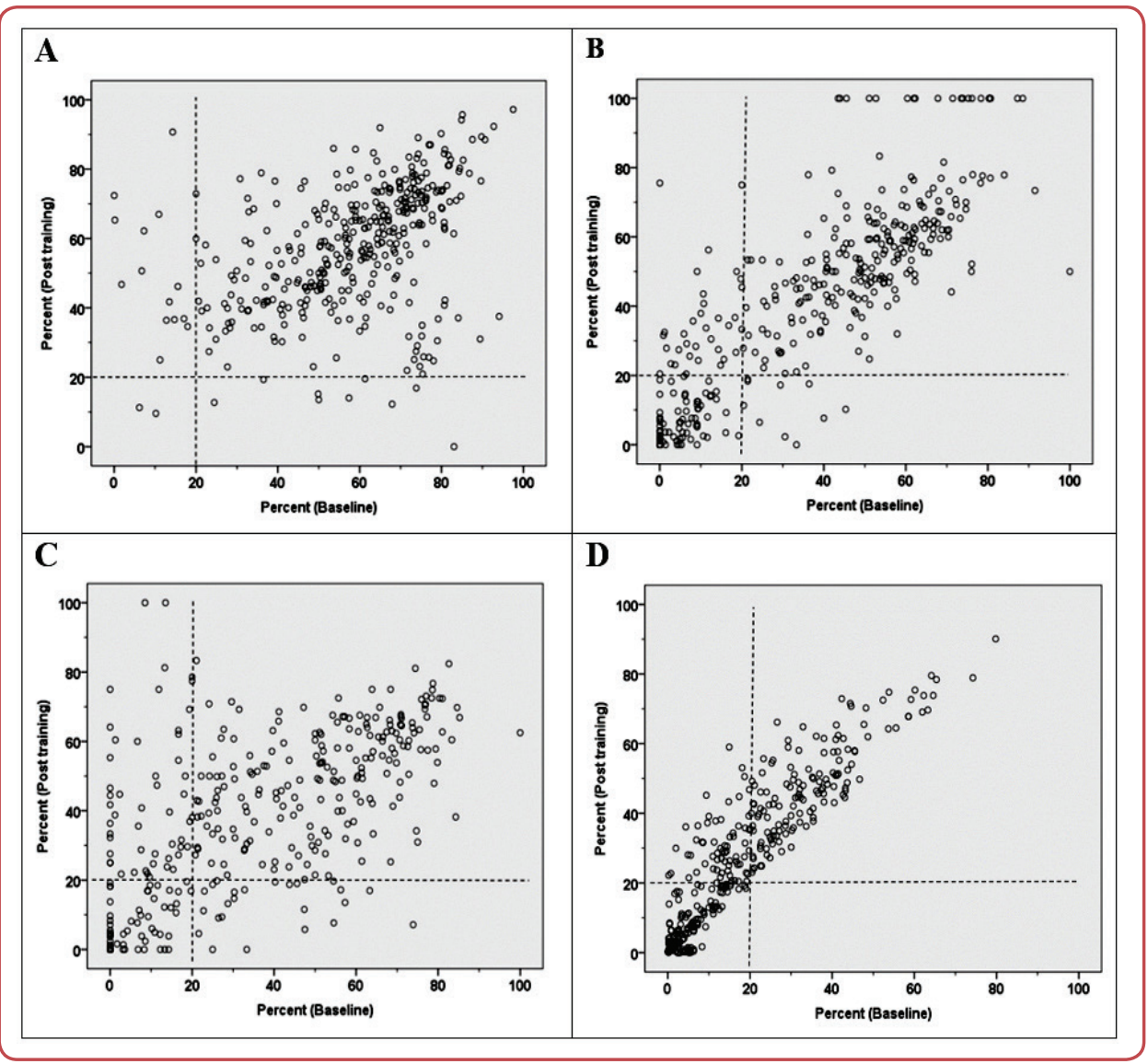

Figure 1: The number of FMTs that recorded the $B P(A), H b A 1 c$ (B), LDL cholesterol (C) and tobacco smoking status (D) in a range less than $20 \%$ before and after CVRAM training.

FMT: family medicine team; $B P$ : blood pressure; LDL: low-density lipoprotein; CVRAM: CardioVascular Risk Assessment and Management. 
Table 3: The achievement of target values for outcome indicators - comparison before and after CVRAM training workshop

\begin{tabular}{lccc}
\hline Indicator & \multicolumn{2}{c}{$\begin{array}{c}\% \text { of patients with } \\
\text { target values }( \pm \text { SD) }\end{array}$} & \multirow{2}{*}{ p value } \\
\cline { 2 - 3 } & Baseline & Post training & \\
\hline $\mathrm{BP}<140 / 90 \mathrm{mmHg}$ & $82.12 \pm 15.81$ & $84.49 \pm 12.71$ & 0.001 \\
\hline $\mathrm{HbA} 1 \mathrm{C}<7 \%$ & $82.64 \pm 26.75$ & $85.49 \pm 24.55$ & 0.001 \\
\hline $\mathrm{LDL}$ cholesterol & $54.98 \pm 20.33$ & $57.64 \pm 16.66$ & 0.001 \\
$<3 \mathrm{mmol} / \mathrm{L}$ & & &
\end{tabular}

CVRAM: CardioVascular Risk Assessment and Management, BP: blood pressure; LDL: Iow-density lipoprotein, BMI: body mass index

found for statin prescribing in group of T2DM patients with high LDL values (indicator 7), but this difference was not statistically significant $(\mathrm{p}=0.320)$.

The BP recording for hypertensive patients has been confirmed in approximately equal percentage before and after CVRAM training $(57.40 \%$ vs $57.06 \%)$. Recording of HbA1c for T2DM patients was improved by $4.96 \%$, the LDL recording was improved by $2.42 \%$, while the body weight measurement recording for obese patients was decreased by $7.6 \%$ (Table 2).

\section{Process indicators}

In order to get more precise insight on process improvement the focus of analysis was put on the number of FMTs that had less than $20 \%$ of recorded data. Having done so, the number of FMTs that had recorded BP values in less than $20 \%$ at the baseline was 18 (5.36\%), but after the training that number decreased to 11 (2.94 $\%)$. The rest of FMTs remained within the values above $20 \%$ (Figure 1A). The HbA1c recording in patients with T2DM was improved in 22 (5.9 \%) FMTs. There were 124 (33.24 \%) FMTs in the range from 0 to $20 \%$ before the training, and 102 $(27.34 \%)$ FMTs after the training (Figure 1B). The LDL cholesterol recording values in patients with hyperlipidaemia was improved in 24 (6.43 \%) FMTs; as many as 139 (37.26 \%) FMTs had less than $20 \%$ of recorded data at the baseline, but after the training the number of FMTs in this range decreased to 115 (30.83\%; Figure 1C). The recording rate of tobacco smoking status in the adult population was improved after education in 62 (16.62 \%) FMTs; before education 228 (61.12 $\%)$ FMTs had recorded this values in less than 20 $\%$, and after the training that number decreased to 166 (44.50\%; Figure 1D).

\section{Discussion}

The cardiovascular risk factors mentioned in this study have been listed by the American Society for Preventive Cardiology as ten essential things to be known about CVD risk factors, emphasising the key activities for health professionals at primary health care level who are facing the fact that many patients have multiple cardiovascular risk factors. ${ }^{10}$ Based on official documents issued by healthcare authorities in our country, the FMTs were obligated to register their patient population into an electronic medical record system. ${ }^{11}$ This prompted the need for assessment of the extent of control and quality of care of CVD risk factors in the registered population and keep registries according to CVD risk factors as well. These registries have provided the first check up and follow up of patients who were informed adequately about healthy lifestyles leading to better CVD risk factors control. Registries of patients with hypertension, DM and CVD risk factors have been included and automatically updated in electronic medical records, serving as a tool for follow up of those patients.

The implementation of clinical guidelines on non-communicable chronic diseases in RS started in $2004 .{ }^{11}$ Since that time there have been several updates of clinical guidelines based on latest recommendations issued by relevant professional associations. The CVRAM training workshop launched additional update of guidelines on hypertension, DM and hyperlipidaemia. ${ }^{12-14}$ The importance of guidelines implementation at primary and secondary level in RS/B\&H was investigated in the past as well. ${ }^{7,15}$

The results of this study showed a decreasing number of hypertensive patients with irregular BP level after CVRAM training workshop. Majority of hypertensive patients had a well-controlled BP and the percentage of those with achieved target values was significantly increased after the training workshop of FMTs. Similarly, Aguilar-Palacio et al found in their study that more than a half of patients had a regular BP, but the increase in BMI worsened the BP control. ${ }^{16}$

The target value for HbA1c was achieved in over $80 \%$ of patients. The percentage of patients with hyperlipidaemia with recorded LDL cholesterol measurement in the last 12 months increased 
and the percentage of patients with hyperlipidaemia with recorded LDL cholesterol $\geq 4.1 \mathrm{mmol} / \mathrm{L}$ in the last 12 months decreased after the training workshop. These improvements showed that the CVRAM training workshop encouraged the FMTs to implement guidelines, making a unique approach to patients with cardiovascular risk. Nonetheless, the percentage of patients treated in accordance with the guideline on hyperlipidaemia was below expectation. Klimchak et al founded that more than a half of sample population was not receiving statin therapy despite of very high burden of atherosclerotic CVD in the United States. ${ }^{17}$ In another study dyslipidaemia was confirmed as the most prevalent risk factor for diabetic patients with consequently increased number of those on statin therapy, but normal LDL and HbA1c levels had been achieved in about one third of patients, suggesting the high correlation between DM diagnosis and low dyslipidaemia control. ${ }^{16}$ This is a challenging task for family physicians worldwide. Low income countries have been facing low socioeconomic status, urbanisation process, specific cultural context and social determinants such as poverty, illiteracy, and ignorance as well as the challenges of traditional medicine. Majority of population in high income countries have urban lifestyles, facing multiple modifiable risk factors and CVD. There is a global need for better compliance with recommendations and improved guidelines adoption. ${ }^{18-20}$

Concerning body weight measurement in this study, a need for improvement in recording of obese patients with measured body weight values has been recognised before and after the training workshop. Training strategies should be adjusted to different capabilities of the FMTs, following the obesity guideline implementation. ${ }^{21}$

Educational activities had an important role in the recording of tobacco smoking, much like in Spain where primary health professionals improved screening of cardiovascular risk factors after educational intervention. They increased the recording of risk factors and thus improved clinical outcomes. ${ }^{22}$ It is necessary to continue with the education on smoking cessation including both professionals and patients according to the guidelines. ${ }^{23}$
The CVRAM training resulted in better implementation of guidelines and this finding is similar to the results of the systematic review of 38 randomised control trials showing better professional adherence to CVD guidelines. ${ }^{6}$ Gil-Guillén et al found improvement in cardiovascular risk factors screening after educational intervention at primary health care level..$^{22}$ This study clearly showed that educational intervention with full implementation of clinical guidelines was particularly effective for the FMTs with low achievements of indicators at baseline assessment. These FMTs really gained from this intervention and it has significantly influenced their approach to cardiovascular risk factors and chronic diseases management. The results of Egan et al showed improved BP control after medical staff training in hypertension management. The BP values in their sample declined in the six months period and 74.3 $\%$ of patients had better hypertension control. ${ }^{24}$ The recording of $\mathrm{BP}, \mathrm{HbA} 1 \mathrm{c}$, LDL, and BMI values, tobacco smoking status, as well as the implementation of training programmes and clinical guidelines are a good basis for planning of preventive actions and improvements in the management of cardiovascular risk factors and CVDs. ${ }^{25}$ Continuing medical education has been implemented widely, but modifications of the training design should be considered.

The major limitation of this study is that not all of the observed FMTs were trained at the same time. The training process lasted one year and the FMTs that were trained at the beginning of training process had almost two years for the implementation of the acquired knowledge and recommendations, while the FMTs that were trained at the end of the training period had only one year for those activities. Comparison between subgroups was not performed in this study. The study was conducted without control group which was another limitation. A different study design, such as a quasi-experimental study with control group, could improve the strength of these findings. However, the study has several strengths: this is the first study, to our knowledge, to evaluate the effects of FMT short training workshop on the cardiovascular risk assessment and management of patients in primary healthcare centres in the RS/B\&H, and second, the study sample size was large enough to enable generalisation of study findings. 


\section{Conclusion}

The CVRAM training workshop and the implementation of clinical guidelines significantly contributed to the better recording of process indicators, as well as to achieving the target values for BP, HbA1c and LDL. The training workshop has primarily helped the poorly organized FMTs, those that had low indicators values before CVRAM training workshop. Short-term training workshop of FMTs on cardiovascular risk assessment and management can improve their practice and healthcare outcomes for patients with CVD and cardiovascular risk factors.

Training programs should be targeted and tailored according to the needs and achievements of specific groups of FMTs and based on updated guidelines. Universal education for all FMTs as a solely intervention, can lead to small changes in quality assurance, but for more effective results, it may require the combination of different approaches for considerable quality improvement.

\section{Acknowledgements}

The authors would like to thank the staff of the WHO Country Office in Bosnia and Herzegovina for their support in conducting the study.

\section{Conflict of interest}

None.

\section{References}

1. World Health Organization, 2018 [Internet]. Global Health Estimates 2016: Deaths by cause, age, sex, by country and by region, 2000-2016. [Cited 01-Jul-2020]. Available from: https://www.who.int/data/gho/data/ themes/mortality-and-global-health-estimates.

2. Kotseva K, Wood D, De Backer G, De Bacquer D, Pyörälä K, Keil U; EUROASPIRE Study Group. Cardiovascular prevention guidelines in daily practice: a comparison of EUROASPIRE I, II, and III surveys in eight European countries. Lancet 2009 Mar 14;373(9667):929-40.
3. Public Health Institute of the Republic of Srpska [Internet]. Analysis of populational health in the Republic of Srpska, Banja Luka 2018. [Cited 01-Jul-2020]. Available from: https://www.phi.rs.ba/index.php?lang=EN.

4. Komić J, Savanović R, Šobot S, Đokić J, Sibinović V, Zec A. Statistical Yearbook of Republic of Srpska, 2019. Banja Luka, the Republic of Srpska: The Republic of Srpska Institute of Statistics; 2019.

5. Ministy of Health and Social Welfare of the Republic of Srpska [Internet]. Low on health protection. Official gazette 2009, 106/09. [Cited 01-Jul-2020]. Available from: https://www.vladars.net/sr-SP-Cyrl/Vlada/Ministarstva/MZSZ/Documents106_09.pdf. [Serbian].

6. Jeffery RA, To MJ, Hayduk-Costa G, Cameron A, Taylor C, Van Zoost C, et al. Interventions to improve adherence to cardiovascular disease guidelines: a systematic review. BMC Fam Pract 2015 Oct 22;16:147. doi: 10.1186/s12875015-0341-7.

7. Pilipovic-Broceta N, Vasiljevic N, Marinkovic J, Todorovic $\mathrm{N}$, Jankovic J, Ostric I, et al. Assessment of hypertension chronic care model: Pacic application in Bosnia and Herzegovina. PLoS One 2018 Aug 14;13(8):e0202250. doi: 10.1371/journal.pone.0202250.

8. World Health Organization. Cardiovascular diseases. [Internet]. [Cited 01-Jul-2020]. Available from: https:// www.who.int/news-room/fact-sheets/detail/cardiovascular-diseases-(cvds).

9. WHO Regional Office for Europe - HO country office in Bosnia and Herzegovina, 2018. Tackling noncommunicable diseases in Bosnia and Herzegovina. [Internet]. [Cited 01-Jul-2020]. Available from: https://www.euro. who.int/data/assets/pdf_file/0011/385076/bos-leaflethr-eng.pdf.

10. Bays HE, Taub PR, Epstein E, Michos ED, Ferraro RA, Bailey AL, et al. Ten things to know about ten cardiovascular disease risk factors. Am J Prev Cardiol 2021 Jan 23;5:100149. doi: 10.1016/j.ajpc.2021.100149.

11. Ministry of Health and Social Welfare of the Republic of Srpska [Internet]. The Primary Health Care Strategy, 2008. [Cited 01-Jul-2020]. Available from: http://www. vladars.net/sr-SPCyrl/Vlada/Ministarstva/MZSZ/Documents/Primarna\%20zastita\%20Brosura.pdf. [Serbian].

12. Ministry of Health and Social Welfare of the Republic of Srpska [Internet]. Primary Health Care Clinical Guidelines. Arterial hypertension, 2015. [Cited 01-Jul-2020]. Available from: http://www.vladars.net/sr-SP-Cyrl/ Vlada/Ministarstva/MZSZ/Documents/13.\%204.\%20 Arterijska\%20hipertenzija.pdf. [Serbian].

13. Ministry of Health and Social Welfare of the Republic of Srpska [Internet]. Primary Health Care Clinical Guidelines. Diabetes and cardiovascular disease, 2015. [Cited 01-Jul-2020]. Available from: http://www.vladars. net/sr-SP-Cyrl/Vlada/Ministarstva/MZSZ/Publikacije/ Documents/19.\%204.\%20Dijabetes\%20i\%20kardiovaskularna\%20bolest.pdf. [Serbian].

14. Ministry of Health and Social Welfare of the Republic of Srpska [Internet]. Primary Health Care Clinical Guidelines. Hyperlipidaemia, 2015. [Cited 01-Jul-2020]. Available from: http://www.vladars.net/sr-SP-Cyrl/Vlada/ Ministarstva/MZSZ/Documents/15.\%204.\%20Hiperlipoproteinemije.pdf. [Serbian].

15. Štrbac S, Rakić S, Aleksić VA, Škrbić R. The role of clinical pathways on healthcare quality improvement in hospitals for patient undergoing total hip replacement. Scr Med 2020;51(2):87-92. 
16. Aguilar-Palacio I, Malo S, Feja C, Lallana M, León-Latre M, Casasnovas JA, et al. Risk factors control for primary prevention of cardiovascular disease in men: Evidence from the Aragon Workers Health Study (AWHS). PLoS One 2018 Feb 23;13(2):e0193541. doi: 10.1371/journal. pone. 0193541

17. Klimchak AC, Patel MY, Iorga ŞR, Kulkarni N, Wong ND. Lipid treatment and goal attainment characteristics among persons with atherosclerotic cardiovascular disease in the United States. Am J Prev Cardiol 2020 May 1;1:100010. doi: 10.1016/j.ajpc.2020.100010.

18. Wekesah FM, Kyobutungi C, Grobbee DE, Klipstein-Grobusch K. Understanding of and perceptions towards cardiovascular diseases and their risk factors: a qualitative study among residents of urban informal settings in Nairobi. BMJ Open 2019 Jun 16;9(6):e026852. doi: 10.1136/ bmjopen-2018-026852.

19. Yusuf S, Joseph P, Rangarajan S, Islam S, Mente A, Hystad P, et al. Modifiable risk factors, cardiovascular disease, and mortality in 155722 individuals from 21 high-income, middle-income, and low-income countries (PURE): a prospective cohort study. Lancet 2020 Mar 7;395(10226):795-808.

20. Enas EA, Varkey B, Gupta R. Expanding statin use for prevention of ASCVD in Indians: Reasoned and simplified proposals. Indian Heart J 2020 Mar-Apr;72(2):65-9.
21. Ministry of Health and Social Welfare of the Republic of Srpska [Internet]. Primary Health Care Clinical Guidelines. Obesity in adults, 2015. [Cited 01-Jul-2020]. Available from: http://www.vladars.net/sr-SP-Cyrl/Vlada/ Ministarstva/MZSZ/Documents/21.\%204.\%20Gojaznost\%20kod\%20odraslih.pdf. [Serbian].

22. Gil-Guillén V, Hermida E, Pita-Fernandez S, Palazon-Bru A, Durazo-Arvizu R, Pallares-Carratala V, et al. A cardiovascular educational intervention for primary care professionals in Spain: positive impact in a quasi-experimental study. Br J Gen Pract 2015 Jan;65(630):e32-40.

23. Ministry of Health and Social Welfare of the Republic of Srpska [Internet]. Primary Health Care Clinical Guidelines. Smoking cessation, 2015. [Cited 01-Jul-2020]. Available from: https://www.vladars.net/sr-SP-Cyrl/ Vlada/Ministarstva/MZSZ/Documents/27.\%204.\%20 Odvikavanje\%20od\%20pusenja.pdf. [Serbian].

24. Egan BM, Sutherland SE, Rakotz M, Yang J, Hanlin RB, Davis RA, Wozniak G. Improving hypertension control in primary care with the measure accurately, act rapidly, and partner with patients protocol. Hypertension 2018 Dec;72(6):1320-7.

25. Piepoli MF, Hoes AW, Agewall S, Albus C, Brotons C, Catapano AL, et al; ESC Scientific Document Group. 2016 European Guidelines on cardiovascular disease prevention in clinical practice. Eur Heart J 2016 Aug 1;37(29):2315-81. 